\title{
On Frames as Isomorphic Structures \\ in Literary Translation \\ (the Example of Qian Zhongshu Translated \\ from Chinese into Russian)
}

\author{
Yaroslav V. Sokolovsky* \\ Siberian Federal University \\ 79 Svobodny, Krasnoyarsk, 660041, Russia
}

Received 11.11.2014, received in revised form 10.12.2014, accepted 16.01.2015

The relation between the original and its translations can be described by a variety of notions: equivalence, adequacy, invariant, etc. Isomorphism is one of such descriptors, though it is not a fullyfledged term in translation studies yet. Here we attempt to prove its applicability to the cognitive theory of translation through the frame analysis of concepts.

Keywords: isomorphism, equivalence, translation, literary translation, translated text, original text, concept, frame.

Research area: philology.

Since the meaning of any linguistic expression depends upon its representation of entities, activities, characteristics, and relations outside of language, the relation of an utterance to its interpretation depends in considerable measure on the degree of isomorphism involved.

Eugene A. Nida, Language and Culture: Contexts in Translating

Social mission of translation and interpreting is a cornerstone underlying the development of this type of human activity. The modern multilingual world not only constantly reveals a need for translation services, but also implies the existence of a certain set of requirements for the quality of translations. "The translator's activity is regulated by social needs, which are shaped by certain social practices" and "the translator may incur criticism and all sorts of sanctions from the client that he (she) serves and those who are called to control the quality of translations (chief editors, translation critics, specialized supervisors in international negotiations, etc.)" (Bakushkina, $2005,12)$. The problem of translation quality in the scientific sense can be re-formulated as a problem of relationship between the original and the translation. The problem of correlation of the

(C) Siberian Federal University. All rights reserved

* Corresponding author E-mail address: sokol-rus@hotmail.ru 
original and translation, in turn, can be viewed through the prism of isomorphism.

In recent years researchers have been paying serious attention to the translation category of isomorphism (Kazakova, 2002; Kulchitskaya, 2000; Razumovskaya, 2006; Bakushkina, 2005, 694; Nida, 2001, 90). At the same time it can be stated that the general theory of translation isomorphism is only in its infancy. In our opinion, one of the solutions to the problem of productive translational isomorphism approach can be a comparative analysis of frame structures in the original and translation texts. In logic, isomorphism can be defined as "a relation between objects of the same, identical structure. If each element of a structure corresponds to only one element of another structure, these two structures are isomorphic" (Kondakov, 1975, 191). The category of isomorphism in translation studies has a solid theoretical foundation conditioned by the epistemological status of interlingual translation, the principle of identity as "an ideal, the ultimate purpose of the translator's work dictated by one of the basic philosophical principles of intellectual and practical activity, and therefore acting on a subconscious level" (Voskoboinik, 2007, 43). Scholars in translation studies often consider isomorphism to be "a condition for translation" (Kazakova, 2002), "a translation tool” (Nida', 1996; 2001, 90) or as "a universal framework for translation" (Bakushkina, 2005, 694). In this regard, we suppose that methodologically speaking the category of isomorphism can be put in one row with such traditional categories of translation correspondence as equivalence, adequacy, invariant, etc.

Translation categories of correspondence have becomeanintegralcomponent of definitions of translation and, consequently, are one of the main reasons for the diversity of perspectives on the translation. In 1998, A. Pym pointed at the circularity of the dichotomy "translation - translation category of correspondence": "equivalence is supposed to define translation, and translation, in turn, defines equivalence. Unfortunately few attempts have been made to define equivalence in translation in a way that avoids this circularity"(RoutledgeEncyclopedia of Translation Studies, 2001, 77). U. Eco also indicates the general blurriness and fuzziness of the concept of "translation" (Eco, 2001, 9). In that connection it is appropriate to recall the opinion of a famous Russian scholar - expert on linguistics - V.A. Zvegintsev, who used to say that "when a researcher does not have a clearly articulated theory and gives priority to the method, the latter takes over the functions of the theory ..." (Zvegintsev, 2008, 77). Any translation categories of correspondence (equivalence, adequacy or something else) clearly define the main vector of semantic transformations carried out by a translator, yet at the same time they are only different methods for solving the problem of approximation of a translation to the original.

The concept of isomorphism, as we noted earlier, may be applied to the theory of translation through the frame-based structure of concepts. The method that we consider here can be described in the following way: in the original text, we select a concept, and then we determine its frame structure in the current context. Afterwards, we analyze the corresponding extract of the translation in order to determine the concept's frame structure in the text of the translation. Afterwards, we need to compare the frames of the original and the translation: if their structures are identical, it means that they are isomorphic (i.e. we have translation isomorphism). If the frame structures are not isomorphic, it means that there is a "structural gap", which can be viewed through the concept of autonomy or selfsufficiency. Before we proceed to illustrating this approach, we want to consider another pair of 
key notions for our paper. These are concept and frame.

It is known that there are many points of view on the linguistic term "concept". In this article, we do not need to have a comprehensive comparative analysis of approaches to the study of this phenomenon, so we restrict ourselves to a description of the invariant features of concept, suggested by a Russian cognitive science scholar V.A. Maslova, who stipulates that the concept: 1) is the smallest unit of a person's experience in its ideal representation, which is verbalized with words and has a field structure; 2) is the basic unit of processing, storage and transmission of knowledge; 3) has flexible boundaries and specific functions; 4) has social nature and its associative field is determined by its pragmatics; 5) is the basic unit of culture (Maslova, 2004, 35). The material, which we analyze further can be attributed to the literary type of text, containing the author's individual concepts. Z.D. Popova and I.A. Sternin, in this regard write that "in order to verbalize some individual-author's concepts it is better to use the text as an optimal means of verbalization; no lexical or phraseological verbalization can cope with the transfer of all shades of individual tints of thought" (Popova, Sternin, 2001, 83).

Now we shall discuss the linguistic term "frame". Analyzing this notion, we may notice the heterogeneity of perspectives of researchers. In particular, N.A. Kulchitskaya gives the following definition to the frame: "a multicomponent, volumetric concept" which is "to the fullest extent linked to the idea of semantic field" (Kulchitskaya, electronic resource). Likewise many domestic linguists regard "frame" as "a type of concept" (Maslova, 2004, 46; Popova, Sternin, 2001, 73). I.A. Tarasova proposes to regard frame "not as a concept, but as a cognitive structure of a higher level, a certain type of interaction between concepts as a way (form) of organization of mental space" (Tarasova, electronic resource). I.M. Kobozeva states that frame is a knowledge structure, which is a package of information about a particular fragment of the human experience. The frame, as she stipulates, is composed of slots, the amount of which correspond to the number of elements to be separated out in this particular snippet of experience: "the slot has a name that specifies a parameter, and is filled with information about the value that this parameter takes in that object type or in this particular instance" (Kobozeva, 2007, 65).

When the linguistic term of frame is under discussion, special attention should be given to the viewpoint of M. Minsky, since he is believed to be the first scholar to use the term "frame" in its well-known meaning (Minsky 1975). He believed that frame can be regarded as a paradigm to understand visual reasoning and natural language processing. M. Minsky postulates that the frame "is a data-structure for representing a stereotyped situation" and "frame can be represented as a network of slots and links between them". "The upper levels" of frame are clearly identified, because they are formed with such notions, that are always valid in relation to the described situation. At lower levels, there are many special terminals or "slots", which can be filled with typical examples or data" (Minsky, 1979, 7). The Russian scholar M.N. Novikov defines a frame structure in a similar way: as slots and relationships, where top levels are fixed and correspond to things that are always true to the assumed situation. They form the basis of the frame. Below these units, we have terminal units, or slots, filling of which depends on the individual experience of a person. The researchers note that when interpreting a message, the person activates a certain contour diagram in which many slots are not yet occupied, and in later episodes he (she) fills these gaps with new data, combines them in a variety of communication chains. 
"The frame is connected, on the one hand, to the verbal language tools, on the other hand, to the cognitive part of consciousness where there is a schematized representation of an image of the person's knowledge, which is activated by the means of language structures" (Novikov, electronic resource).

In this study, we consider frame not as a concept, but as a structural form of its representation, and frame analysis as a method that allows us to single out cognitive structures, representing a certain concept. The method of frame analysis of concepts is in detail described in the dissertation by Z.I. Moiseeva (Moiseeva, 2007) and is based on the authoritative opinion of the domestic scholar Zh.V. Nikonova. The sequence of frame analysis, according Z.I. Moiseeva, goes as follows: 1) the definition of an invariant (basic, prototypical) model concept in a particular language; 2) the comparison of the invariant frame model (frame) with the frame structure options in the text and definition of variant terminal slots in the text; determining the causes and extent of differences of prototypical structures with the textual ones; 3) analysis of all cases of variability of the frame structure and their classification (Moiseeva, 2007, 79).

To illustrate this approach, we have completed frame analysis of the structure of the concept “教育” (English - Education; Russian Образование) in some fragments of the original known Chinese novel “围城” (English - Besieged Fortress; Russian - Осаждённая крепость), written by Qian Zhongshu (钱钟书), and the corresponding fragments of its translation into Russian. The text that we used for our study was translated by a famous Russian literary translator of the $20^{\text {th }}$ century, an expert on the Chinese language V. Sorokin. Afterwards the frame structures were compared and isomorphism was stipulated. Let us describe briefly the course of our research.
To determine the prototypical model of the concept "Education" in the Chinese language picture of the world it was necessary to analyze its semantic representation and describe its semantic scope. For further analysis, we shall use the term “教育” in order to emphasize the specificity of the Chinese concept.

There are many ways to describe the semantic volume of a concept. In this study, we used two popular methods: 1) the use of the semantic approach to the interpretation of concepts using a partial definition of systemlinguistic meanings (synonyms and antonyms), 2) associative experiment. Our technique of associative experiment involved presenting a keyword-stimulus “教育” to informants, and then we asked the informants to write the first 5 reactions that came to their mind (words or phrases) as a response to the word-stimulus. When processing the results of the experiment we took all associates into account, including single ones. 80 informants took part in the experiment: 35 students and 10 teachers of Heilongjiang University (Harbin, China), and 35 students of the Eastern Institute (Harbin, China). We believe that for fundamental experimental investigation of the concept this number of informants is obviously not enough, but in our study it seems sufficient: we need to identify only basic "reference points" for the description of the concept and its prototype for subsequent analysis of the original and the translation. The age of students was 18-20 years, teachers - 3040 years. The mother language of the informants is Chinese. In the experiment we obtained 497 associative reactions.

Based on the results of our research, the semantic volume of the concept “教育” can be described as a set of the following points:

- a process of educating a new generation;

- a process carried out in schools;

- transfer of knowledge and moral norms; 
- aprocess thatfacilitatesthecomprehension of the truth;

- a way of human thinking (can have both positive and negative consequences);

- has a relationship with politics and state of society;

- a process of assuming responsibility for their actions;

- a teacher, a student;

- educational institutions;

- diligence, solidarity, mutual aid;

- the future, civilization, culture.

Analysis of the most frequent reactions in our associative experiment shows that layers containing axiological components (estimation) of this concept are centered around the reactions “勤 奋” (diligence), “团结” (cohesion, unity), “互助” (mutual assistance), i.e. reactions characterized by positive connotative composition. The "subject" level involves 1) associates of people - the transmitter of knowledge: “老师” (teacher) and recipient of knowledge - “学生” (student), 2) associates of place (location) for the implementation of education: “教室” (study room), “学校” (school) “大学” (University), 3) elements of the educational process: “考试” (exams), “课程” (course, subject, discipline). The symbolic perception of the concept by the native speakers is related to “未来” (the future), “文明” (civilized, enlightened), “文化” (culture). In addition, a significant number of informants pointed at a link between educational process and acquisition of knowledge (知识, 学问).

Analyzing the semantic volume of the concept, we noted that certain parts of the semantic volume are often contradictory: in particular, education as a way to influence people's minds can be interpreted as good or as harm. In addition, despite the apparent prevalence of positive assessments among associates, the share of negative assessments is also noticeable. Such contradictions point to the potential variation in the frame structure of this concept. In this regard, Z.I. Moiseeva writes that in one specific context both components of the semantic volume of a concept cannot be reflected in the same lexical unit, and "different contexts of use will highlight only certain parts of the whole concept" [Moiseeva, 2007: 103].

When we were considering the original literary text, we were pursuing two objectives: 1) to identify in these fragments of the original certain meanings that correlate with the concept “教育”，2) to compare the original with the investigated part of the translated text. The frame analysis we carried out resulted in the following structure ${ }^{2}$ :

The first most frequently detected conceptual meaning was "profanation of education, visibility of education instead of its actual essence". This conceptual meaning can be seen in the following passages of the original Chinese and translated Russian text:

“这一张文凭, 仿佛有亚当、夏娃下身那片树 叶的功用, 可以遮羞包丑; 小小二方纸能把一个 人的空疏、寡婳、愚笨都掩盖起来。自己没有文 凭, 好像精神上赤条条的, 没有包裹” (钱, 2007, 10).

“Диплом - это фиговый листок, что прикрывал срам прародителей наших Адама и Евы; за ним можно спрятать свою никчемность, серость, тупость. Без диплома человек ощущает себя так, как будто его голым выставили на всеобщее обозрение" (Qian, 1989, 34).

The second meaning, which is frequently encountered in the original and translated text, is "education is a tool to control your mind":

“这不是大教授干政治, 这是小政客办教 育。从前愚民政策是不许人民受教育, 现代愚民 政策是只许人民受某一种教育。不受教育的人, 因为不识字, 上人的当, 受教育的人, 因为识了 字, 上印刷品的当, 像你们的报纸宣传品、训练 干部讲义之类” (钱, 2007, 138). 
“Беда не в том, что крупные политики вырастают из педагогов, а в том, что судьбы просвещения вершат мелкие политиканы. Раньше держали народ в темноте, не давая ему никакого образования, теперь оглупляют его, давая ему только то образование, которое считают нужным. Прежде люди страдали из-за неграмотности, сейчас это грамотные жертвы газет и всякой пропагандистской макулатуры" (Qian, 1989, 158).

Next, we may single out the following semantic slot: "education for a girl is an obstacle for her happy marriage":

“有头脑有才学的女人是天生了教笨的男人 向她颠倒的 <... > 女人有女人的特别的聪明, 轻 盈活泼得跟她的举动一样。比了这种聪明, 才学 不过是沉淀渣漳。说女人有才学, 就仿佛赞美一 朵花, 说它在天平上称起来有白菜番薯的斤两。 真聪明的女人决不用功要做成才女, 她只巧妙的 偷懒” (钱, 2007, 84-85).

“Толковым и одаренным женщинам на роду написано вызывать страсть у глупцов. <..> Для женщины предпочтителен особый склад ума: легкий, изящный, как их движения. Учёность рядом с таким умом - тяжелый осадок, выпадающий на дно. Хвалить женщину за ученость - все равно что восхищаться букетом цветов лишь из-за его веса. Действительно умная женщина не должна утруждать себя наукой” (Qian, 1989, 110).

Another semantic slot of the frame which complements the invariant kernel "profanation of education..." is the slot "teaching is not a prestigious occupation":

“别胡闹, 我对教书没有兴趣。若有水田三 百亩, 来年不作猢狲王” (钱, 2007, 137).

“Не болтайте чепухи. Просто меня не интересует преподавание. Как сказал поэт, “будь у меня триста му земли, стал бы я возиться с этими мартышками!” (Qian, 1989, 157).
Thus, the frame structure of the concept “教 育" (Education / Образование) of the analyzed fragments of the original and the translation turns out to be isomorphic. It can be represented as the top invariant kernel "profanation of education, visibility of education instead of its actual essence", complemented by the following terminal slots: "education is a tool to control your mind", "education for a girl is an obstacle for her happy marriage" and "teaching is not a prestigious occupation". We are certain that the terminal conceptual meanings that we found do not come in conflict with the top invariant meaning, but they rather complement it.

The following graph gives a visual picture of the frame structure of the concept “教育” (Education / Образование) in the fragments that we have considered (the top kernel is number 1 and the three terminal slots are 2, 3 and 4, respectively:

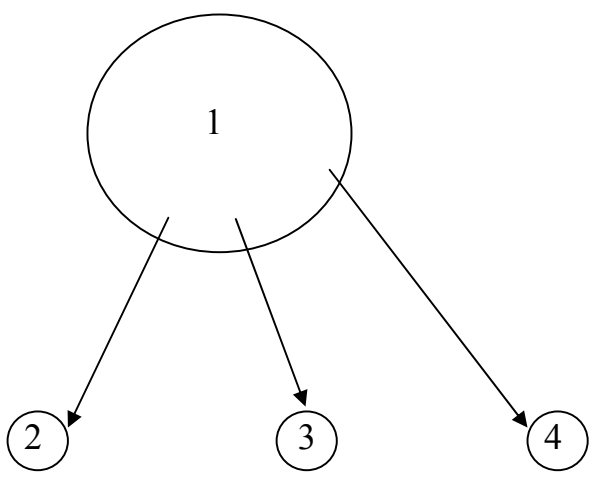

Since the text we deal with here is a literary text, special attention should be paid to the "explicatory markers" of the conceptual meanings. The most important type of explicatory markers that may stand behind conceptual meanings in this type of text are stylistic means, which are typical for the literary style of language (epithets, figures of speech, metaphors, etc.).

In general, it is worth of note that each of our suggested fragments contains certain markers of the conceptual meaning (i.e. slot). This type 
of approach provides for a wide variation in linguistic expressions of the same conceptual meaning: in other words, despite the fact that the translation of one explicatory marker can be replaced with another (synonymous), yet the relationship of isomorphism between the frames remains.

It is important to remember that the concept of isomorphism, as we have emphasized, is only one of the models describing the correlation between the original and its translation. In this respect, one should remember the words of professor L.S. Barkhudarov, a famous Russian scholar in translation studies, that "translation is a too complex and multifaceted phenomenon to completely fit into the inevitably limited scope of any one model or theoretical scheme. The more of these models and diagrams we have the better, the more we shall find out about the essence of translation" (Problems in the theory of translation in the works of prof. L.S. Barkhudarov, 1987, 9).

\footnotetext{
Eugene A. Nida was an outstanding linguist, one of the founders of the modern discipline of Translation Studies and we regard him as a founder of modern translation isomorphism. In the future, we intend to write a separate paper devoted to his understanding of isomorphs and isomorphism in translation studies.

2 Due to the limited size of the article we give just one example of each conceptual meaning that we distinguished.
}

\section{References}

1. Bakushkina, I.A. Measuring semantic and structural similarity of the original and the translation: on the material of translations of texts of various genres from German into Russian [Izmereniye semantiko-strukturnoy analogichnosti originala i perevoda: na materiale perevodov tekstov razlichnykh zhanrov s nemetskogo yazyka na russkiy ]: Ph. D dissertation in philology: 10.02.20 Moscow (Russian State Library), 2005.

2. Bradford L. R. The Limits of Literary Translation: Expanding Frontiers in Iberian Languages. Translation Studies, 2015. Volume 8, Issue 1. Pp. 112-115 DOI: 10.1080/14781700.2014.965730

3. Eco, U. Experiences in Translation. Toronto, Buffalo, London, 2001.

4. Kazakova, T.A. Isomorphism as a condition of translation [Izomorfizm kak usloviye perevoda]. Proceedings of the 3rd International Scientific Conference on Translation Studies "Fedorov Readings" (Materialy 3y mezhdunarodnoy nauchnoy konferentsii po perevodovedeniyu "Fedorovskiye chteniya"). Saint Petersburg: Publishing House of St. Petersburg State University, 2002, pp.274-284.

5. Kobozeva, I.M. Linguistic semantics [Lingvisticheskaya semantika]. Moscow: KomKniga, 2007.

6. Kondakov, N.I. Logic Reference Dictionary [Logicheskiy slovar'-spravochnik] M: Nauka, 1975.

7. Kulchitskaya, L.V. On the concept of isomorphism as a methodological basis of the theory of equivalence [O kontseptsii izomorfizma kak metodologicheskoy baze teorii ekvivalentnosti ]. Proceedings of the First International Scientific Conference on Translation Studies "Fedorov Readings". Saint Petersburg: Publishing House of St. Petersburg State University, 2000, pp. 101107.

8. Kulchitskaya, N.A. Frame as a type of lexical concept: new views on the issue of the frame in linguistics [Freym kak tip leksicheskogo kontsepta: o novykh vzglyadakh na problemu freyma $\mathrm{v}$ lingvistike] (Electronic resource). Available at http://www.rusnauka.com/ONG/Philologia/7_kul_ chickaja\%20n.a..doc.htm (December 15, 2014). 
9. Lee T.K. Asymmetry in translating heterolingualism: A Singapore case study Perspectives: Studies In Translatology, 2009, v. 17 n. 1, p. 63-75 DOI: http://dx.doi.org/10.1080/09076760902825925

10. Maslova, V.A. Cognitive linguistics [Kognitivnaya lingvistika]. Minsk: TetraSistems, 2004.

11. Minsky, M. A Framework for Representing Knowledge. In Pat Winston. The Psychology of Computer Vision. New York: McGraw Hill. 1975, pp. 211-277.

12. Minsky, M. Frames for representation of knowledge [Freymy dlya predstavleniya znaniy]. Moscow: Energy, 1979.

13. Moiseeva, Z.I. Concepts "Solidaritat" and "Wohlstand" and variability of frame structure in the German political discourse [Kontsepty «Solidaritat» $\mathrm{i}$ «Wohlstand» i variativnost' ikh freymovoy struktury v nemetskom politicheskom diskurse]: Ph. D. Dissertation in Linguistics: 10.02.04. Moscow (Russian State Library), 2007.

14. Nida, E. A. Isomorphic connections and equivalence in translation [Izomorphie svyazi I ekvivalentnost' v perevode]. Translation and Communication (Perevod I Kommunikatsia). Moscow, Russian Academy of Sciences, 1996, pp. 35-41.

15. Nida, E. A. Language and Culture: Contexts in Translating. Shanghai: Shanghai Foreign Language Education Press, 2001.

16. Novikov, M.N. Activation of the frame as a way to specify the target audience in advertising [Aktivizatsiya freyma kak sposob ukazaniya na tselevuyu auditoriyu reklamy] (Electronic resource). Available at http://www.lomonosov-msu.ru/2007/09/NovikovMaxim.doc.pdf (December 2, 2014).

17. Popova, Z.D. Sternin I.A. Essays on Cognitive Linguistics [Ocherki po kognitivnoy lingvistike ]. Voronezh: Publishing House of VSU, 2001.

18. Problems of translation studies in the works of prof. L.S. Barkhudarov [Voprosy teorii perevoda v trudakh prof. L.S. Barkhudarova]. Interpreter's Notebook: academic-theoretical collection (Tetradi perevodchika: nauchno-teoreticheskiy sbornik). Issue 22. Moscow: Higher School (Vysshaya shkola), 1987, pp.6-9.

19. Protopopova, I. The concept of the educational program "Cognitive Studies" [Kontseptsiya obrazovatel'noy programmy "Kognitivnyye issledovaniya"] (Electronic resource) Available at http:// kogni.narod.ru/concept.htm (October 8, 2014).

20. Qian Zhongshu. Besieged fortress [Osazhdonnaya krepost']: novels, short stories. Moscow: Literature, 1989.

21. Razumovskaya, V.A. Isomorphism of the poetic text in the aspects of poetics and translation [Izomorfizm poeticheskogo teksta $\mathrm{v}$ aspektakh poetiki i perevoda]. Bulletin of the Krasnoyarsk State University (Vestnik Krasnoyarskogo gosudarstvennogo universiteta) 20066 / 2. Krasnoyarsk: Publishing House of Krasnoyarsk State University, 2006, pp. 55-58.

22. Routledge Encyclopedia of Translation Studies. London and New-York: Routledge, 2001.

23. Tarasova, I.A. Categories of cognitive linguistics in the study idiostyle [Kategorii kognitivnoy lingvistiki v issledovanii idiostilya] (Electronic resource) Available at http://weblib.ssu.samara.ru/ DLib/vestnik/documents/200411601.html (March 25, 2014).

24. Voskoboinik, G.D. The dialectics of identity and cognitive dissonance: the question of the formation of translation episteme [Dialektika tozhdestva i kognitivnogo dissonansa: $\mathrm{k}$ voprosu $\mathrm{o}$ stanovlenii perevodcheskoy epistemy]. Asia-Pacific region: a dialogue of languages and cultures: a collection of scientific papers of the international conference (20-31 January 2007) (Aziatsko- 
Tikhookeanskiy region: dialog yazykov i kul'tur: sbornik nauchnykh dokladov mezhdunarodnoy konferentsii (20-31 yanvarya 2007)/ Ed. by O.M. Gotlib. Irkutsk: Irkutsk State Linguistic University, 2007, pp. 43-48.

25. Zvegintsev, V.A. Thoughts on linguistics [Mysli o lingvistike]. Moscow: Publishing House of LCI, 2008.

26. 钱,钟书，围城 .- 北京: 生活, 读书, 新知三联书店, 2007.

\title{
К вопросу об изоморфных структурах \\ в художественном переводе \\ (на примере перевода Цянь Чжуншу \\ с китайского языка на русский)
}

Я.В. Соколовский

Сибирский федеральный университет

Россия, 660041, Красноярск, пр. Свободньій, 79

\begin{abstract}
Соотношение оригинала и перевода может быть рассмотрено различными категориями: эквивалентностю, адекватностью, инвариантами и иными. Изоморфизм является одной из таких категорий. В свою очередь, одним из продуктивных решений проблемы переводческого изоморфизма может быть сопоставительный анализ фреймовой структуры концептов в текстах оригинала и перевода.
\end{abstract}

Ключевые слова: изоморфизм, эквивалентность, перевод, художественный перевод, переводной текст, оригинальный текст, кониепт, фрейм.

Научная специальность: 10.00.00 - филологические науки. 